Stilistika: Jurnal Bahasa, Sastra, dan Pengajarannya

ISSN 2527-4104

Vol. 1 No.1, 1 April 2016

\title{
PERGESERAN BAHASA SASAK DI SEBAMBAN KABUPATEN TANAH BUMBU
}

\author{
Kamariah dan Muhammad Abdillah \\ STKIP PGRI Banjarmasin \\ Kamariahm.pd@gmail.com
}

\begin{abstract}
Abstrak
Penelitian ini bertujuan untuk, (1) mengungkapkan pergeseran bahasa Sasak (2) mengungkapkan karakteristik pergeseran bahasa Sasak (3) mengungkapkan faktor-faktor yang memengaruhi pergeseran bahasa Sasak Kabupaten Tanah Bumbu.

Pendekatan yang digunakan adalah pendekatan kualitatif. Pendekatan yang digunakan dalam penelitian ini bersumber dari masyarakat tutur dalam ranah keluarga pada masyarakat suku Sasak sebagai objek penelitian karena berdasarkan teori bahwa keluarga merupakan tempat seseorang memperoleh bahasa dalam hal ini bahasa Sasak.

Simpulan penelitian ini adalah (1) sikap masyarakat Sasak terhadap pergeseran bahasa, ada satu pembahasan, (2) karakteristik peregeseran bahasa Sasak yaitu: a) domain keluarga satu pembahasan, b) domain pendidikan satu pembahasan, c) domain perdagangan satu pembahasan, d) domain perkantoran satu pembahasan, (3) Faktor-faktor yang mempengaruhi pergeseran bahsa Sasak, a) faktor internal satu pembahasan, b) faktor ekternal tiga pembahasan yaitu faktor pendidikan, faktor perekonomian dan faktor kawin campur.
\end{abstract}

Kata kunci : pergeseran, bahasa sasak

\section{PENDAHULUAN}

Masyarakat suku Sasak di Sebamban desa Karang Intan adalah migrasi dari provinsi Nusa Tenggara Barat ke Sebamban Desa Karang Intan Kecamatan Kuranji Kabupaten Tanah Bumbu. Migrasi tersebut dikarenakan kebijakan pemerintah sebagai upaya pemerataan penduduk. Selain itu tanah di Sebamban desa Karang Intan memiliki tanah yang subur, tersedianya lahan pertanian dan perkebunan yang luas. Ketersediaan sumber daya alam itulah yang menjadi faktor utama masyarakat suku Sasak bermigrasi.

Kebanyakan penutur Bahasa Sasak sudah bergeser dan beradaptasi dengan bahasa dan dialek di lingkungan sekitarnya, hal itu dikarenakan banyak penuturnya yang merasa malu memakainya. Apalagi pada usia di bawah 30 tahun atau usia remaja, seperti pemuda-pemuda banyak terjadi pergeseran yang mengakibatkan banyaknya kata yang berubah makna bahkan hilang sama sekali atau tidak digunakan di karenakan pergaulan luar, dan media elektronik seperti televisi dan alat elektronik lainnya. Penutur bahasa Sasak ini seperti merasa enggan untuk berbicara mencolok dan lebih memilih membiasakan diri untuk menggunakan bahasa Indonesia atau bahasa suku lain seperti bahasa Banjar dan Jawa.

Pergeseran bahasa (language shifting) yakni penggunaan bahasa oleh seorang penutur atau sekelompok penutur yang terjadi akibat perpindahan dari satu 
masyarakat tutur ke masyarakat tutur yang lain. Pergeseran bahasa umumnya mengacu pada proses penggantian satu bahasa dengan bahasa lain dalam repertoir linguistik suatu masyarakat. Dengan demikian, pergeseran bahasa mengacu pada hasil proses penggantian satu bahasa dengan bahasa lain. Sementara itu, pemertahanan bahasa menyangkut masalah sikap atau penilaian terhadap suatu bahasa untuk tetap menggunakan bahasa tersebut di tengah-tengah bahasa lainnya.

Di samping itu juga faktor mitra tutur, situasi, topik, dan fungsi interaksi dapat juga menyebabkan pergeseran bahasa. Berdasarkan hal tersebut terlihat bahwa terjadinya pergeseran bahasa lebih terkait dengan faktor lingkungan bahasa.Beberapa kondisi cenderung dihubung-hubungkan terhadap pergeseran bahasa.Kondisi yang paling mendasar barangkali adalah kedwibahasaan (bilingualism). Tetapi patut diperhatikan dengan seksama bahwa kedwibahasaan ini bukanlah satu-satunya faktor yang menyebabkan pergeseran bahasa. Kedwibahasaan tidak dengan serta merta menyebabkan pergesaran bahasa, meskipun ini merupakan salah satu syarat terjadinya pergeseran bahasa. Kasus-kasus pergeseran bahasa hampir seluruhnya terjadi melalui alih generasi (intergenerasi). Maksudnya adalah pergeseran bahasa memerlukan waktu lebih dari satu generasi.

Persaingan bahasa muncul dalam penggunaannya oleh setiap individu. Dalam hal ini, memperhatikan beberapa keluarga asli suku Sasak. Pada hampir semua keluarga tersebut terdapat tiga bahasa dominan yang mereka gunakan, yaitu bahasa Sasak, bahasa Banjar atau bahasa suku lain, dan bahasa Indonesia. Terlihat jelas dalam keluarga bagaimana ketiga bahasa tersebut digunakan. Bahasa Sasak lebih banyak digunakan oleh kaum dewasa dengan sesamanya seperti bahasa yang digunakan antara suami dan isteri (ayah dan ibu), antara ayah-ibu dengan kakeknenek, atau antara ayah-ibu dengan paman-bibi. Sedangkan bahasa Banjar atau bahasa suku lain dan bahasa Indonesia, lebih banyak digunakan antara ayah-ibu dengan anak-anak, antara kakek-nenek dengan cucu, atau antara paman-bibi dengan keponakan.

Jika diperhatikan bahwa dalam keluarga-keluarga suku Sasak tersebut terdapat dua kelompok penutur yaitu kelompok dewasa yang secara aktif menggunakan bahasa Sasak dan kelompok anak-anak yang lebih dominan menggunakan bahasa Banjar dan bahasa suku lain atau bahasa Indonesia. Jika pendatang tersebut merupakan orang asli suku Sasak meskipun umurnya masih belum dikatakan dewasa maka ayah-ibu akan berinteraksi dalam bahasa Sasak, sedangkan anak-anak akan menggunakan bahasa Banjar dan bahasa suku lain atau bahasa Indonesia. Namun jika pendatang adalah orang dari suku lain maka komunikasi kebanyakan menggunakan bahasa Banjar dan bahasa suku lain atau bahasa Indonesia.

Dalam berbagai acara keluarga besar yang dilakukan oleh kumpulan keluarga suku Sasak di Sebamban, maka bahasa Sasak tetap digunakan hanya oleh kalangan dewasa, sedangkan anak-anak akan lebih banyak menggunakan bahasa Banjar atau bahasa suku lain dan bahasa Indonesia. Pemilihan bahasa tersebuttidak didasarkan pada topikyang dibicarakan, ataupun tempat, namun lebih cenderung pada lawan bicaraatau dengan siapa dialog itu terjadi. Jika dialog itu terjadi pada kelompok dewasa maka secara otomatis bahasa yang digunakan adalah bahasa Sasak, namun jika dialog itu terjadi antara anggota kelompok dewasa dengan anggota kelompok 
anak-anak, maka secara otomatis pula pilihan bahasa akan berubah menjadi bahasa Banjar atau bahasa suku lain atau bahasa Indonesia.

Selain itu karakteristik pergeseran bahasa juga ditandai dalam domaindomain. Diantaranya domain keluarga, domain pendidikan, domain perdagangan, domain perkantoran/pemerintahan dan lain-lain. Domain keluarga biasaya memiliki karakteristik yakni semakin pudarnya penggunaan bahasa dalam domain keluarga. Namun tidak semua masyarakat yang melupakan bahasa asli mereka tetapi ada sebagian dari penutur yang masih setia menggunakan bahasa asli mereka.

Domain pendidikan biasanya ditandai dengan tingginya intensitas penggunaan bahasa Indonesia dan digunakannya bahasa dari suku lain. Dalam domain pendidikan khususnya di sekolah anak-anak cenderung menggunakan bahasa Indonesia sebagai alat berkomunikasi dengan guru dan menggunakan bahasa suku lain karena pengaruh pergaulan yang dianggap lebih bergengsi.

Karakteristik pergeseran bahasa dalam domain perdagangan biasanya terjadi karena faktor kebutuhan transaksi antara penjual dan pembeli. Sama halnya dengan domain pendidikan, dalam domain perdagangan juga cenderung menggunakan bahasa Indonesia sebagai saran komunikasi saat transaksi jual-beli. Tak jauh beda dengan domain pendidikan dan perdagangan, domain perkantoran lebih banyak menggunakan bahasa Indonesia. Domain perkantoran/pemerintahan ditandai dengan semakin tinggi jabatan atau kedudukan seseorang maka semakin tinggi intensitas penggunaan bahasa Indonesia.

Penting diingat, kedwibahasaan itu bukanlah satu-satunya kondisi bagi pergeseran, walaupun mungkin yang diperlukan. "Hampir semua kasus pergeseran bahasa terjadi melalui alih generasi (intergenerasi), menyangkut lebih dari satu generasi. Dengan kata lain, jarang terjadi sejumlah besar individu dalam masyarakat menanggalkan bahasa dan mengganti dengan bahasa lain dalam kurun hidupnya" (Sumarsono, 2004:235).

Salah satu faktor yang mempengaruhi adalah migrasi atau perpindahan penduduk, yang bisa berwujud dua kemungkinan. Pertama, kelompok-kelompok kecil bermigrasi ke daerah atau negara lain yang tentu saja menyebabkan bahasa mereka tidak berfungsi di daerah baru. Kedua, gelombang besar penutur bahasa bermigrasi membanjiri sebuah wilayah kecil dengan sedikit penduduk, menyebabkan penduduk setempat terpecah dan bahasanya tergeser.

Secara sederhana dapat dikatakan bahwa pergeseran bahasa itu terjadi ketika masyarakat (komunitas bahasa) memilih suatu bahasa baru untuk mengganti bahasa sebelumnya. Dengan kata lain, pergeseran bahasa itu terjadi karena masyarakat bahasa tertentu beralih ke bahasa lain, biasanya bahasa domain dan berprestise, lalu digunakan dalam ranah-ranah pemakaian bahasa yang lama.

Perkembangan ekonomi juga merupakan faktor pendorong pergeseran. Salah satu faktor ekonomi itu adalah industrialisasiyang kadang-kadang bergabung dengan faktor migrasi). Kemajuan ekonomi kadang-kadang mengangkat posisi sebuah bahasa menjadi bahasa yang mempunyai nilai ekonomi tinggi. Bahasa Inggris misalnya, menjadi minat banyak orang untuk menguasai dan kalau perlu meninggalkan bahasa pertama.Sekolah sering juga dituding sebagai faktor penyebab bergesernya bahasa ibu, karena sekolah biasanya mengajarkan bahasa asing kepada anak-anak, demikian 
ini kemudian menjadi dwibahasawan. Padahal kedwibahasaan seperti kita ketahui mengandung resiko bergesernya salah satu bahasa (Sumarsono, 2004:236-237).

Pada umumnya sekolah atau pendidikan sering juga menjadi penyebab bergesernya bahasa, karena sekolah selalu memperkenalkan bahasa kedua (B2) kepada anak didiknya yang semuala monolingual, menjadi dwibahasawan dan akhirnya meninggalkan atau menggeser bahasa pertama (B1) mereka. Faktor lain yang banyak oleh para ahli sosiolinguistik adalah faktor yang berhubungan dengan faktor usia, jenis kelamin, dan kekerapan kontak dengan bahasa yang lain. Rokhman (2013:53) dalam kajiannya mengidentifikasikan tiga faktor yang mempengaruhi pergeseran dan pemertahanan bahasa pada masyarakat, yakni faktor sosial, kultural, dan situasional.

Pergeseran bahasa merupakan bentuk perubahan bahasa dalam jumlah yang signifikan. Konsep ini mengacu pada situasi di mana komunitas penutur mulai menggunakan bahasa baru secara keseluruhan, atau dengan kata lainberhentimenggunakan bahasa lama mereka untuk kebutuhan komunikasi mereka.Pergeseran bahasa biasanya terjadi dari generasi ke generasi yang berbeda. Di Indonesia beberapa penelitibahasadaerah (Jawa, Bali, Sunda, Madura, dll) khawatir dengan berkurangnya jumlah pengguna bahasa daerah yang mengikuti pergeseran ke arah penggunaan bahasa Indonesia. pergeseran bahasa biasanya ditemukan pada generasi muda.

Sumber data dalam penelitian ini adalah bahasa yang dituturkan oleh penutur asli suku Sasak dan konteks tuturan yang diperoleh melalui obsevasi dan pencatatan secara langsung. Subjek penelitian yang dipilih dalam penelitian ini adalah masyarakat asli penutur suku Sasak. Namun dalam hal ini tidak semua penutur dapat dijadikan informan dalam penelitian sebab terdapat syarat-syarat yang harus dipenuhi untuk menjadi informan. Analisis data dilakukan selama dan setelah pengumpulan data. Maksudnya pengumpulan data ditranskipkan dan disesuaikan dengan catatan peneliti.

\section{PEMBAHASAN}

\section{A. Sikap Masyarakat Sasak Terhadap Pergeseran Bahasa Sasak}

Pergeseran bahasa Sasak dapat dilihat dengan semakin berkurangnya penggunaan bahasa Sasak oleh masyarakat suku Sasak di Sebamban Desa Karang Intan. Pergeseran Bahasa Sasak dapat dibuktikan dari banyaknya penutur bahasa Sasak asli yang justru lebih memilih menggunakan bahasa lain, seperti bahasa Banjar dan bahasa Indonesia. Masyarakat suku Sasak lebih cenderung menggunakan bahasa Indonesia dan bahasa suku lain dalam berinteraksi tergantung dengan lawan bicaranya.

Meskipun dalam domain keluarga Sasak (ayah-ibu) masih menggunakan bahasa Sasak namun tidak dapat dipungkiri, ayah-ibu lebih cenderung menggunakan bahasa Indonesia atau bahasa Banjar ketika berinteraksi dengan anak-anak mereka dibandingkan menggunakan bahasa Sasak itu sendiri. Untuk membuktikan dan mengetahui jumlah penutur bahasa Sasak dan pengguna bahasa lain peneliti membagikan 40 lembar kuesioner, 20 diantaranya merupakan kepala keluarga dan 20 
lainnya adalah anak-anak usia di bawah 20 tahun. 40 orang yang menerima itu sebagai sampel dari keseluruhan penutur bahasa Sasak.

Masyarakat Sasak yang menggunakan Bahasa Sasak asli hanya sebanyak 7 orang. Penutur yang menggunakan bahasa Sasak asli hanyalah kaum tua dengan rentang usia 60 sampai 81 tahun. Sebagian besar masyarakat Sasak menggunakan dua bahasa atau lebih. Anak-anak muda suku Sasak yang berusia 17 sampai 21 tahun lebih banyak menggunakan bahasa Indonesia dalam sehari-hari, dikarenakan bahasa yang harus digunakan di sekolah. Sedangkan bahasa Banjar yang digunakan oleh anak-anak muda suku Sasak dikarenakan faktor pergaulan. Bahasa Banjar banyak digunakan oleh anak-anak muda Sasak ketika berkumpul dan berinteraksi dengan penutur lain baik di lingkungan Desa Karang Intan maupun di lingkungan luar. Mayoritas masyarakat Sasak mengalami kedwibahasaan, 27 orang penutur yang di teliti menggunakan dua bahasa atau lebih.

Kedwibahasaan masyarakat Sasak terjadi karena beberapa masyarakat Sasak menikah dengan suku lain. Perkawinan campur itulah yang menjadi penyebab utama masyarakat Sasak mampu menggunakan dua bahasa atau lebih. Seperti yang dijelaskan oleh salah seorang penutur Sasak yaitu Hakiyah (28 tahun) dalam kutipan wawancara bersama peneliti:

Percakapan 1

“..... Saya lahir dari keluarga suku Sasak asli, mama sama bapak orang Lombok (Sasak) jadi otomatis bisa bahasa Lombok. Tapi pas saya kawin sama bapaknya (suami) yang orang Banjar jadi saya harus pakai bahasa Indonesia supaya sama-sama ngerti. Terus anak-anak saya sekarang malah terbiasa pakai bahasa Banjar, soalnya ikut bahasa bapaknya dan saya juga ikut pakai bahasa Banjar karena suami saya pakai bahasa Banjar". (Hakiyah, 28 tahun).

Berdasarkan percakapan 1 bahwa kedwibahasaan penutur suku Sasak disebabkan oleh perkawinan campur. Awalnya penutur Sasak hanya menggunakan bahasa Indonesia agar mudah berkomunikasi dengan suaminya yang merupakan penutur bahasa Banjar. Namun setelah memiliki anak penutur Sasak justru ikut menggunakan bahasa Banjar dikarenakan anak-anak menggunakan bahasa Banjar mengikuti bahasa yang biasa digunakan oleh orang tuanya. Kondisi tersebut dikarenakan penggunaan bahasa Banjar lebih dominan digunakan ketika berinteraksi di rumah sehingga menyebabkan tidak dikenalkannya bahasa Sasak kepada anakanak.

Dari hasil kuesioner yang dibagikan diperoleh persentase penutur bahasa Sasak hanya sebesar $20 \%$, dari persentase tersebut sebagian besar penutur bahasa Sasak adalah kaum tua seperti kakek-nenek, ayah-ibu, paman-bibi.

Percakapan 2

Penutur Sasak 1 : "Mbe Taoq Me Kuliah Anak Me?" (Anak Kamu Kuliah Dimana?)

Penutur Sasak 2 : “Le' Banjarmasin" (Di Banjarmasin) 


\section{Penutur Sasak 1 : "Pirane Uleq Yok Bale?" (Kapan Pulang ke rumah?) \\ Penutur Sasak 2 : “Julun uwieq" (Kemarin).}

Percakapan 2 dilakukan oleh Saimah, 81 tahun dan Idrus, 71 tahun. Keduanya merupakan kaum tua yang masih menggunakan bahasa Sasak. Kaum tua suku Sasak biasa menggunakan bahasa Sasak ketika berkomunikasi dengan sesama penutur Sasak yang masuk ke dalam golongan kaum tua. Kesetiaan kaum tua dalam menggunakan bahasa Sasak digunakan hanya dalam ranah keluarga. Kaum tua cenderung menggunakan bahasa Sasak ketika berkomunikasi dengan sesama penutur bahasa Sasak namun, ketika berkomunikasi dengan penutur lain kaum tua pun menggunakan bahasa Indonesia dengan alasan agar lebih mudah dimengerti oleh lawan bicara atau penutur lain.

Pergeseran bahasa Sasak jelas terlihat dengan dominannya penggunaan bahasa Indonesia. Sebanyak $60 \%$ penutur bahasa Indonesia adalah anak-anak muda suku Sasak. Pemilihan bahasa Indonesia dikarenakan anak-anak muda menganggap bahwa bahasa Sasak sulit dimengerti oleh lawan bicara. Era-modern ini masyarakat Sasak dalam pergaulan banyak sekali anak-anak muda yang meninggalkan bahasa Sasak yang merupakan bahasa yang dipakai di rumahnya.

Penggunaan bahasa Banjar oleh masyarakat Sasak merupakan bentuk pergeseran bahasa Sasak yang sangat jelas terjadi. Penggunaan bahasa Banjar dengan persentase $20 \%$ digunakan oleh anak-anak muda suku Sasak yang bermigrasi ke tempat lain.

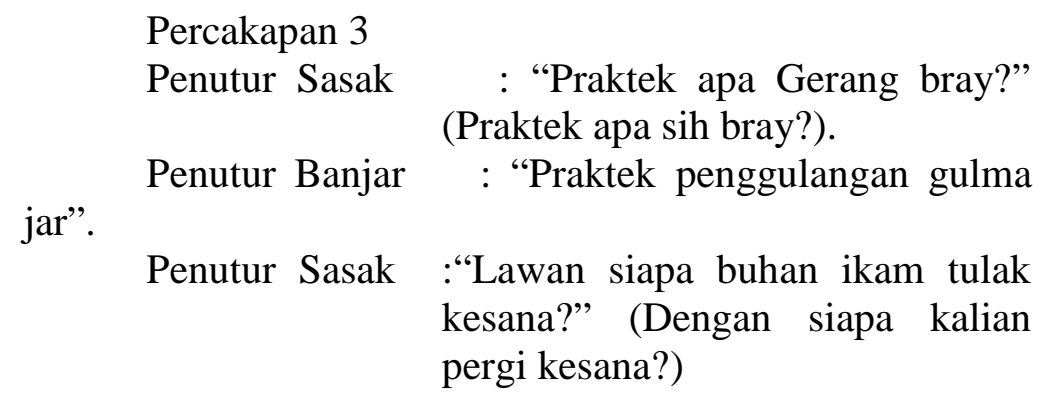

Dari kutipan percakapan 3 penutur Sasak (Baharuddin, 23 tahun seorang Mahasiswa Fakultas Pertanian Unlam) memilih menggunakan bahasa Banjar untuk berkomunikasi dengan lawan bicaranya. Penggunaan bahasa Banjar oleh penutur Sasak semata-mata hanya untuk membuat jarak antara penutur Sasak dan penutur Banjar lebih dekat agar lebih mengerti maksud dari pembicaraan.

Bahkan yang lebih menarik penutur Sasak bisa menggunakan dwibahasa secara bersamaan. Anak-anak muda suku Sasak lebih memilih menggunakan bahasa Indonesia dan bahasa Banjar. Menurut mereka bahasa Banjar lebih bergengsi dibandingkan dengan bahasa Sasak sedangkan bahasa Indonesia merupakan bahasa yang dibawa dari lingkungan sekolah. Hal itulah yang membuat bahasa Sasak semakin mengalami pergeseran, masyarakat suku Sasak tidak lagi menggunakan 
bahasa Sasak untuk berkomunikasi kepada anak-anak. Selain itu pada acara-acara besar masyarakat suku Sasak lebih memilih menggunakan bahasa Indonesia.

Penggunaan bahasa Indonesia dinilai lebih mudah dimengerti pada saat berkomunikasi dengan penutur lain. Anak-anak muda suku Sasak mulai malu untuk menggunakan Bahasa Sasak dalam berkomunikasi sehari-hari, ini dikarenakan Bahasa Sasak memiliki logat yang aneh dan sulit dimengerti oleh penutur lain. Anakanak muda cenderung menggunakan Bahasa Indonesia, Bahasa Banjar dan kadang bercampur dengan bahasa lainnya, hasilnya banyak remaja saat ini mengaku malu ketika menggunakan Bahasa Sasak. Bahkan semenjak kecil anak-anak sudah dibiasakan menggunakan Bahasa Indonesia oleh orang tuanya daripada menggunakan Bahasa Sasak. Dengan lunturnya penggunaan Bahasa Sasak di kalangan remaja, hal yang sangat memprihatinkan sebagian besar anak-anak suku Sasak adalah tidak dapatnya menggunakan Bahasa Sasak yang merupakan bahasa ibu mereka.

Anak-anak muda suku Sasak lebih memilih menggunakan bahasa Indonesia dengan mencampurkan bahasa modern dalam berkomunikasi. Anak-anak suku Sasak beranggapan bahwa bahasa Sasak yang dimilikinya merupakan bahasa ndeso atau bahasa kampungan. Bahkan lebih memilih menggunakan bahasa Banjar karena dianggap lebih bergengsi. Proses sosial sesuai dengan keadaan kalangan anak-anak muda suku Sasak sekarang ini, diantaranya perubahan penggunaan bahasa dalam pola interaksi. Anak-anak yang masih berstatus sekolah mulai tidak menggunakan bahasa Sasak dalam berinteraksi baik di sekolah maupun di lingkungan masyarakat yang menyebabkan perubahan gaya hidup kalangan muda suku Sasak. Anak-anak muda suku Sasak mulai menggunakan bahasa Nasional, bahasa Banjar dan mulai tidak menggunakan bahasa Sasak. Hal yang paling dominan adalah adanya kontak Bahasa dengan bahasa nasional atau bahasa Indonesia.

Terjadinya kontak dengan bahasa nasional disini adalah tingkat keseringan dan intensitas memakai bahasa nasional, baik berdasarkan pemakaian aktif maupun pasif. Tingkat pendidikan formal seseorang berpengaruh juga terhadap bahasa daerah atau bahasa ibunya. Tingkat pendidikan formal tinggi berkaitan erat dengan tingkat keseringan dan intensitas pemakaian bahasa Nasional (Sumarsono, 2004:366).

Selain itu tingkat pendidikan formal seseorang juga berpengaruh dengan intensitas penggunaan bahasa Nasional. Semakin tinggi pendidikan formal seseoarang maka semakin sering dan intensif kontak dengan bahasa Nasional. Demikian pula, status sosial tinggi sehubungan dengan jenis pekerjaan dan kedudukan seseorang. Semakin tinggi jabatan seseorang, baik dalam sektor pemerintahan maupun swasta maka semakin sering pula intensitas penggunaan bahasa Nasional.

\section{B. Karakterisrik Pergeseran Bahasa Sasak}

Karakteristik yang mempengaruhi terjadinya pergeseran bahasa Sasak adalah tidak digunakanya lagi bahasa Sasak oleh masyarakat Sasak khususnya oleh kaum muda suku Sasak. Karakteristik inilah yang menjadi awal mula terjadinya pergeseran bahasa Sasak. Bahkan penggunaan bahasa lain dimulai dari domain keluarga yang merupakan tempat seharusnya bahasa Sasak itu diperkenalkan sejak awal. Sebagian besar orang tua lebih memilih menggunakan bahasa Indonesia dengan alasan untuk 
membiasakan anak-anak mereka. Berikut beberapa karakteristik Pergeseran Bahasa Sasak yang dapat terlihat dari beberapa domain.

\section{Domain Keluarga}

Karakteristik Pergeseran Bahasa pada domain keluarga terlihat pada penggunaan bahasa Sasak yang tidak digunakan lagi oleh keluarga suku Sasak. Penggunaan bahasa Sasak biasanya hanya digunakan oleh kaum tua yakni ayah-ibu, kakek-nenek, paman-bibi. Tetapi ketika kaum tua (ayah-anak, nenek-cucu ) berbicara dengan anak-anak muda justru menggunakan bahasa Indonesia. Seperti yang di katakan oleh bapak Khalidi, 49 tahun seorang pegawai di kelurahan Desa Karang Intan yang merupakan kaum tua suku Sasak.

Percakapan 4

“..... Kebanyakan orang tua di sini mempelajari

anak ya pakai bahasa Indonesia. Biar gampang nanti

ngomong sama gurunya kalo sekolah" (Khalidi, 49

tahun).

Berdasarkan kutipan 4 alasan utama kaum tua menggunakan bahasa Indonesia adalah agar anak-anak terbiasa menggunakan bahasa Indonesia sehingga lebih mudah berkomunikasi ketika bersekolah. Tidak dapat dipungkiri bahwa perkembangan zaman memang menuntut kaum tua juga harus mengikuti kemajuan zaman tersebut. Begitu pula dengan kaum tua suku Sasak harus mengikuti kemajuan zaman tersebut dengan mengenalkan bahasa Indonesia kepada anak-anak mereka.

\section{Domain Pendidikan}

Pada umumnya sekolah atau pendidikan sering juga menjadi penyebab bergesernya bahasa, karena sekolah selalu memperkenalkan bahasa kedua kepada anak didiknya yang semula monolingual, menjadi dwibahasawan dan akhirnnya meninggalkan atau menggeser bahasa pertama. Hal ini seperti yang tampak pada percakapan murid dengan guru:

Percakapan 5

Murid : "Pak, pabila bagi rapot? Ulun handak liburan"(Pak, kapan bagi rapot? Saya mau liburan.

Guru : "Kita bagi rapot hari Sabtu".

Murid : " Iyakah Pak, Kuitan kah pak yang meambil akan? "(oh begitu, orang tua kah pak yang mengambilkan?)

Guru : "Iya orang tua kalian".

Murid : "Kalo misalkan diwakilkan boleh apa tidak pak?"

Guru : iya boleh

Berdasarkan kutipan percakapan 5 bahwa dalam domain pendidikan yang diambil sampel di SMP Negeri 2 Kuranji, mayoritas siswa lebih dominan menggunakan dua bahasa sekaligus. Dominannya penggunaan bahasa Banjar dikarenakan letak sekolah yang berdekatan langsung dengan komunitas penutur bahasa Banjar. Faktor geografis itulah yang membuat anak-anak muda suku Sasak yang sekolah cenderung menggunakan bahasa Banjar, sedangkan penggunaan bahasa Indonesia lebih cenderung digunakan pada saat berbicara dengan penutur lain.

\section{Domain Pasar}


Pasar merupakan tempat paling memungkinkan terjadinya kontak tutur antara antar bahasa yang dilakukan oleh penjual dan pembeli. Tempat dimana digunakannya berbagai macam bahasa dan penutur bahasa tanpa terkecuali bahasa Sasak. Namun tidak dapat dipungkiri bahwa domain pasar juga berpengaruh akan bergesernya sebuah bahasa. Penggunaan kedwibahasaan tidak dapat dihindarkan karena penutur bahasa harus menggunakan bahasa sesuai dengan keperluan agar mempermudah dalam bertransaksi. Berikut kutipan bahasa yang digunakan dalam domain pasar oleh seorang penutur Sasak.

Percakapan 6

Penutur Banjar : "Berapa harga tapih mang?" (berapa harga sarung paman)

Penutur Sasak : “Rp. 75.000,- haja, murah kalo?” (Rp. 75.000,- aja, murah kan?)

Penutur Banjar : "Kada kawa kurang kah mang?" (Tidak bisa kurang kah paman?)

Penutur Sasak : "Haraga Rp. 70.000,- nah pasnya" (Harga Rp.70.000,- pasnya)

Dalam kutipan percakapan 6 yang dilakukan oleh Ridwan, (48 tahun) yang merupakan seorang pedagang dan seorang penutur Sasak asli. Penutur Sasak menggunakan bahasa Banjar karena pembeli yang harus dilayaninya adalah seorang penutur Banjar dengan tujuan agar lebih mudah bertransaksi. Keragaman bahasa dan variasi bahasa yang terjadi di pasar membuat penggunaan bahasa Sasak sangat jarang digunakan, kecuali hanya dengan penutur Sasak yang melakukan transaksi jual-beli.

\section{Domain Perkantoran}

Pergeseran sebuah bahasa juga dipengaruhi oleh status sosial. Status sosial yang tinggi berhubungan dengan jenis pekerjaan dan kedudukan seseorang. Semakin tinggi jabatan seseorang, baik dalam sektor pemerintahan maupun swasta maka semakin sering pula intensitas penggunaan bahasa Nasional dan tidak lagi menggunakan bahasa ibunya. Contoh dalam kutipan percakapan berikut:

Percakapan 7

Penutur 1 : "kemarin sudah tak kasih saran soal surat dinas"

Penutur 2: "coba dikasih uang aja, 50 aja supaya lancar urusannya"

Penutur 1: "Dia enggak mau pak, katanya enggak boleh gitu"

Penutur 2: "Ini kan untuk kepentingan dinas juga pak".

Dari kutipan percakapan 7 dilakukan oleh Ali Akbar, 29 tahun (Pegawai Dinas) yang merupakan penutur Sasak. Tingkat status sosial dan tingkat jabatan berpengaruh juga dalam penggunaan bahasa Sasak. Semakin tinggi kedudukan atau semakin formalnya pekerjaan seseorang maka semakin tinggi intensitas penggunaan bahasa Nasional yang menyebabkan penutur tidak lagi menggunakan bahasa ibunya. 


\section{Faktor-faktor yang Mempengaruhi Pergeseran Bahasa Sasak}

Penggunaan bahasa Sasak di Sebamban Desa Karang Intan Kecamatan Kuranji Kabupaten Tanah Bumbu mengalami pergeseran. Banyak masyarakat Sasak menggunakan bahasa percampuran dengan bahasa lain. Penggunaan bahasa lain yang digunakan oleh anak-anak muda suku Sasak khususnya. Pergeseran bahasa tidak begitu saja terjadi, tetapi pergeseran bahasa tersebut di dorong oleh beberapa faktor, yaitu faktor internal dan faktor eksternal.

\section{Faktor Internal}

Faktor internal yang dimaksud merupakan penyebab terjadinya pergeseran Bahasa Sasak yang dilakukan oleh masyarakat Sasak yang terjadi dalam lingkungan Desa Karang Intan Kecamatan Kuranji Kabupaten Tanah Bumbu. Faktor dari masyarakat Sasak itu sendirilah yang menjadi penyebab bergesernya bahasa, khususnya anak-anak muda suku Sasak. Dalam hal ini adalah rendahnya kesadaran dan kemampuan dalam menggunakan Bahasa Sasak. Banyak anak muda suku Sasak yang ada di Desa Karang Intan yang mulai berkurang kemampuannya dalam menggunakan Bahasa Sasak.

Sesuai dengan hasil observasi yang ada di lapangan, hal ini lebih menunjukan bahwa kemampuan anak-anak muda terhadap penggunaan Bahasa Sasak telah tergeserkan. Kemampuan berbahasa Sasak kurang juga karena tidak didukung oleh orang tuanya karena tidak dibiasakan menggunakan Bahasa Sasak yang lebih baik. Orang-orang tua malah bersikap biasa ketika kemampuan anak-anak muda suku Sasak dalam menggunakan bahasa Sasak terdengar buruk.Selain itu remaja merasa malu menggunakan bahasa Sasak. Terutama ketika bersama teman-temannya saat berada dalam lingkungan sekolah. Di lingkungan sekolah banyak teman-teman daerah lain sehingga banyak anak-anak muda suku Sasak lebih menggunakan Bahasa Indonesia daripada bahasa Sasak. Bahasa Sasak juga tidak digunakan oleh anak-anak muda ketika keluar dari lingkungan Sebamban Desa Karang Intan. Anak-anak muda suku Sasak malu akan logat aneh yang di keluarkan, karena terdengar lucu dan terkesan kampungan. Sehingga anak-anak muda suku Sasak seringkali tidak menggunakan Bahasa Sasak dan anak-anak muda suku Sasak lebih cenderung menggunakan bahasa Indonesia dan bahasa Banjar di bandingkan Bahasa Sasak.

Selain itu, faktor lain penyebab bergesernya bahasa Sasak di Desa Karang Intan Kecamatan Kuranji Kabupaten Tanah Bumbu adalah semakin berkurangnya sikap menghargai bahasa Sasak sebagai bahasa penting dalam keluarga. Kepedulian terhadap bahasa yang semakin menipis pada diri anggota keluarga dalam menggunakan bahasa Sasak sebagai alat komunikasi pada ranah keluarga mereka.

\section{Faktor Eksternal}

Faktor eksternal yang dimaksud merupakan penyebab terjadinya perubahan Bahasa Sasak yang di lakukan oleh masyarakat Sasak yang terjadi di luar lingkungan Sebamban Desa Karang Intan Kecamatan Kuranji Kabupaten Tanah Bumbu.

\section{a. Faktor Pendidikan}

Pada umumnya sekolah atau pendidikan sering juga menjadi penyebab bergesernya bahasa, karena sekolah selalu memperkenalkan bahasa kedua kepada 
anak didiknya yang semula monolingual, menjadi dwibahasawan dan akhirnya meninggalkan atau menggeser bahasa pertama. Hal ini seperti yang terjadi di sekolah yang dikunjungi oleh peneliti adalah banyak anak-anak muda yang lebih senang menggunaan bahasa Indonesia dan bahasa Banjar.

Persaingan era-globalisasi memang membuat bahasa lain menjadi salah satu komponen yang harus dikuasai dalam berkomunikasi. Sebagai bahasa Nasional, keterampilan menguasai bahasa yang lain tentu menjadi nilai lebih dalam kualifikasi peluang dunia kerja. Namun, jika penggunaan bahasa lain hanya untuk pencitraan belaka maka hal tersebut menjadi salah. Seringkali anak-anak muda beranggapan agar terlihat keren dan berpendidikan. Bahasa lain yang sering di pelajari dalam sekolah adalah Bahasa Banjar. Bahasa Banjar merupakan salah satu mata pelajaran Muatan Lokal yang masih digunakan di sekolah.

Selain itu, faktor pendidikan juga menyebabkan pergeseran bahasa ibu pada murid, karena sekolah biasa mengajarkan bahasa asing kepada anak-anak. Hal ini menyebabkan anak-anak menjadi dwibahasawan. Padahal, kedwibahasaan mengandung resiko bergesernya salah satu bahasa. Secara sederhana dapat dikatakan bahwa pergeseran bahasa itu terjadi ketika masyarakat memilih suatu bahasa baru untuk mengganti bahasa sebelumnya.

\section{b. Faktor Perekonomian}

Selain itu faktor ekonomi juga merupakan penyebab pergeseren bahasa. Salah satu faktor ekonomi itu adalah industrialisasi. Industralisasi merupakan peristiwa penggunaan bahasa lain yang disebabkan oleh tuntutan perekonomian (pekerjaan). Misalkan, seorang pemuda Sasak yang pergi kedaerah lain untuk bekerja kemudian pemuda tersebut ikut menggunakan bahasa yang digunakan di daerah tersebut dan akhirnya kembali ke daerah asalnya sambil membawa dan justru menggunakan bahasa yang digunakan di tempat ia bekerja sehingga melupakan bahasa Sasaknya.

\section{c. Faktor Perkawinan Campur}

Perkawinan campur juga merupakan faktor yang berpengaruh dalam pergeseran bahasa Sasak. Dalam domain keluarga yang melakukan perkawinan campur akan ada salah satu bahasa yang akan mengalamai pergeseran dikarenakan agar lebih mudah dalam berkomunikasi. Selain itu dampak faktor perkawinan campur akan berdampak pada keturunan atau anak-anak, secara tidak langsung anak-anak mereka juga harus memilih salah satu bahasa untuk berkomunikasi. Biasanya bahasa yang diturunkan kepada anak-anak adalah bahasa yang lebih dominan digunakan dalam keluarga tersebut. Sehingga menyebabkan salah satu bahasa dari penutur yang melakukan perkawinan campur tersebut tidak lagi digunakan dan mengalami pergeseran. Sebagai contoh seorang penutur Sasak yang melakukan perkawinan campur dengan penutur Banjar. Dalam kasus ini bahasa yang lebih dominan digunakan adalah bahasa Banjar karena intensitas penggunaanya lebih besar dalam keseharian. Tidak hanya itu dampak dari perkawinan campur adalah anak-anak dari keluarga tersebut ikut menggunakan bahasa Banjar karena terbiasa berkomunikasi dengan bahasa Banjar. Hal tersebut mengakibatkan tidak digunakanya bahasa Sasak sehingga mengakibatkan terjadinya pergeseran bahasa Sasak.

\section{PENUTUP}




\section{Simpulan}

Berdasarkan hasil penelitian dan pembahasan maka dapat ditarik kesimpulan sebagi berikut :

a. Pergeseran bahasa Sasak dapat dibuktikan dari banyaknya penutur bahasa Sasak asli yang justru lebih memilih menggunakan bahasa lain, seperti bahasa Banjar dan bahasa Indonesia. Anak-anak muda suku Sasak lebih banyak menggunakan bahasa Indonesia dalam sehari-hari, dikarenakan bahasa yang harus digunakan di sekolah dan pergaulan.

b. Karakteristik Pergeseran Bahasa pada masyarakat Sasak dapat diamati dari beberapa domain. Pertama, domain keluarga penggunaan bahasa Sasak biasanya hanya digunakan oleh kaum tua yakni ayah-ibu, kakek-nenek, paman-bibi. Kedua, domain sekolah selalu memperkenalkan bahasa kedua kepada anak didiknya yang semula monolingual, menjadi dwibahasawan dan akhirnnya meninggalkan atau menggeser bahasa pertama. Ketiga, domain Penutur Sasak menggunakan bahasa Banjar karena pembeli yang harus dilayaninya adalah seorang penutur Banjar dengan tujuan agar lebih mudah bertransaksi. Penggunaan Bahasa Sasak oleh masyarakat Sasak mengalami pergeseran, pergeseran tersebut disebabkan masyarakat suku Sasak khususnya anak-anak muda telah menggunakan Bahasa Indonesia yang didapatkan sewaktu di sekolah. Anak-anak muda suku Sasak juga kurang mendapatkan pendidikan dalam penggunaan Bahasa Sasak baik di rumah maupun lingkungan masyarakat.

c. Faktor-faktor yang mempengaruhi pergeseran bahasa Sasak adalah (1) Faktor internal yaitu kurangnya intensitas pemakaian Bahasa Sasak (2) faktor eksternal yaitu kedwibahasaan yang didapat dari lingkungan pendidikan, faktor ekonomi, yakni industrialisasi yang memaksa masyarakat Sasak untuk bekerja ke daerah lain sehingga melupakan bahasa aslinya dan faktor perkawinan campur yang dilakukan oleh suku Sasak.

2. Saran

Berdasarkan simpulan penelitian dapat diajukan beberapa saran. Sejumlah saran yang dimaksud adalah sebagai berikut.

a. Masyarakat Sasak di Sebamban Desa Karang Intan Kecamatan Kuranji Kabupaten Tanah Bumbu Harus menggunakan Bahasa Sasak. Bahasa Sasak merupakan salah satu kebudayaan asli suku Sasak yang tinggal di Desa Karang Intan yang harus dilestarikan.

2. Bagi generasi muda suku Sasak agar berperan serta melestarikan bahasa Sasak di Desa Karang Intan Kecamatan Kuranji Kabupaten Tanah Bumbu sehingga tetap bertahan dalam kedudukannya sebagai bahasa ibu pada masyarakat Sasak. 


\section{DAFTAR RUJUKAN}

Asi, N. (2014). Pergesaran Bahasa Dayak Ngaju dalam Keluarga Suku Dayak Ngaju di Palangkaraya. (N. Asi, Performer) Seminar Linguistik IV STKIP PGRI Banjarmasin, Banjarmasin, Kalimantan Selatan, Indonesia.

Chaer, A., \& Agustina, L. (2010). Sosiolinguistik Perkenalan Awal. Jakarta: Rineka Cipta.

Indrawan, M. I. (2012). Sociolinguistic: The Study of Societies' Language. Yogyakarta: Graha Ilmu.

Rafiek, M. (2009). Sosiolinguistik: Kajian Multidisipliner. Malang: Universitas Negeri Malang.

Rokhman, F. (2013). Sosiolinguistik, Suatu Pendekatan Pembelajaran Bahasa dalam Masyarakat Multikultural. Semarang: Graha Ilmu.

Sumarsono, \& Partana, P. (2004). Sosiolinguistik. Yogyakarta: Pustaka Pelajar. 